\title{
A Review of Clinical Trial Endpoints of Patients with Pulmonary Arterial Hypertension and Chronic Thromboembolic Pulmonary Hypertension and How They Relate to Patient Outcomes in the United States
}

\author{
Christine Divers, PhD; David Platt, MD; Edward Wang, PharmD, MBA; Jay Lin, PhD, MBA; \\ Melissa Lingohr-Smith, PhD; and Stephen C. Mathai, MD, MHS
}

\section{SUMMARY}

Pulmonary arterial hypertension (PAH) and chronic thromboembolic pulmonary hypertension (CTEPH) are subgroups of pulmonary hypertension and are considered rare diseases. Understanding how endpoints of clinical trials (and patient registry studies) of patients with PAH and CTEPH are associated with patient outcomes is important in order to address the concerns of patients, health care providers, decision makers, and payers. The purpose of this review was to examine how endpoints used in clinical trials and patient registry studies are associated with outcomes of patients with PAH and CTEPH.

A PubMed literature search was conducted to retrieve published studies, including randomized phase III clinical trials and observational studies, from years 2000 to May 2015 that evaluated the associations between change in 6-minute walking distance (6MWD), 6MWD thresholds, change in World Health Organization functional class (WHO-FC), and time to clinical worsening with outcomes of patients with PAH and CTEPH.

Based on this review of published literature, a reduction in 6MWD as a criterion for PAH worsening, a deterioration in WHO-FC, and delay in the time to clinical worsening are clinically meaningful trial endpoints and are associated with outcomes of patients with PAH and CTEPH. Utilization and standardization of these endpoints will be useful for comparing interventions of clinical trials and therapies. Hospitalizations are frequent among patients with PAH and CTEPH, and total health care costs are high. From a U.S. payer perspective, clinical worsening is an important composite endpoint in that it includes hospitalization, which can be transformed into a preventative cost value associated with efficacious treatment of patients with PAH and CTEPH. In view of the greater number of medications available to treat $\mathrm{PAH}$, the introduction of the first approved therapy to treat $\mathrm{CTEPH}$, and the increasing use of combination pharmacotherapy, reliable prognostic markers of treatment responsiveness are important to help guide appropriate management. As new clinical trials and observational studies are conducted, it will be important to maintain universal endpoints so that health care providers, decision makers, and payers can better understand the value of targeted pharmacotherapies and combination therapies for the treatment of patients with PAH and CTEPH.

J Manag Care Spec Pharm. 2017;23(1):92-104

Copyright $\odot 2017$, Academy of Managed Care Pharmacy. All rights reserved.

\section{What is already known about this subject}

Pulmonary arterial hypertension (PAH) and chronic thromboembolic pulmonary hypertension (CTEPH) are rare diseases associated with significant morbidity and high mortality.

Some studies have found that the health care and economic burdens of patients with PAH and CTEPH are substantial, although because of the lack of specific coding for these rare diseases, there is a level of uncertainty regarding the true burden of PAH and CTEPH.

In view of the greater number of medications available to treat $\mathrm{PAH}$ and the introduction of the first approved therapy to treat CTEPH, reliable prognostic markers of treatment responsiveness are important to help guide appropriate management.

\section{What this study adds}

This review describes the endpoints of clinical trials and observational studies of patients with PAH and CTEPH and how they relate to patient outcomes.

Based on this review of published literature, a reduction in 6-minute walking distance as a criterion for PAH worsening, a deterioration in World Health Organization functional class, and delay in the time to clinical worsening are clinically meaningful trial endpoints and are associated with outcomes of patients with PAH and CTEPH.

As new clinical trials and studies of patient registries are conducted, it will be important to maintain universal endpoints so that health care providers, decision makers, and payers can better understand the value of new targeted pharmacotherapies and combination therapies for the treatment of patients with PAH and CTEPH.

$\mathrm{P}$ ulmonary arterial hypertension (PAH) is a progressive disease resulting from restricted flow through the pulmonary arteries and leading to increased pulmonary vascular resistance and ultimately right heart failure and death. ${ }^{1}$ Chronic thromboembolic pulmonary hypertension (CTEPH) is similar to PAH but is caused by obstruction of the 
pulmonary arteries with intraluminal organized thrombus. ${ }^{2}$ $\mathrm{PAH}$ and CTEPH are subgroups of pulmonary hypertension $(\mathrm{PH})$ and are considered rare diseases. ${ }^{1,2}$ In the United States, the prevalence of PAH per 1 million individuals is estimated at 109 among persons aged $<65$ years and at 451 among persons aged $\geq 65$ years. $^{3}$ The prevalence of CTEPH per 1 million individuals is estimated at 63 among persons aged $<65$ years and at 1,007 among persons aged $\geq 65$ years. $^{3}$ Other studies conducted in Europe have reported lower prevalence of PAH and CTEPH. ${ }^{4,5}$ Using registry data from France, the prevalence of PAH was reported as 15-25 cases per million adults. ${ }^{4}$ Based on a registry in Spain, the prevalence of CTEPH was reported as 3.2 cases per million adults. ${ }^{5}$ The true prevalence of PAH and CTEPH is difficult to gauge, since both lack specific diagnostic coding to distinguish from other types of $\mathrm{PH}$ and are frequently underdiagnosed and/or misdiagnosed. ${ }^{6,7}$ The prognosis of either PAH or CTEPH is poor..$^{1,2}$ The 1-, 3-, 5-, and 7-year survival rates of patients with $\mathrm{PAH}$ were estimated at $85 \%, 68 \%, 57 \%$, and $49 \%$, respectively, based on the U.S. Registry to Evaluate Early and Long-term Pulmonary Arterial Hypertension Disease Management (REVEAL Registry) study. ${ }^{8}$ Among patients with inoperable CTEPH, the 1- and 3-year survival rates were estimated at $82 \%$ and $70 \%$, respectively, based on a study in the United Kingdom. ${ }^{9}$

The pathogenesis of PAH is predominately related to loss of vascular luminal cross section resulting from vascular tissue remodeling, with excessive vasoconstriction also contributing in approximately $20 \%$ of patients. ${ }^{1}$ CTEPH arises from emboli, which become fibrotic scar tissue that progressively causes microvascular lesions and vascular remodeling. ${ }^{1}$ CTEPH can occur as a complication (2\%-4\% cumulative incidence) after pulmonary embolism (PE); however, many CTEPH patients have no history of PE. ${ }^{1,10,11}$ Hemodynamically, PAH and CTEPH are defined by a mean pulmonary artery pressure (PAP) $\geq 25 \mathrm{mmHg}$ at rest, a pulmonary artery wedge pressure $\leq 15$ $\mathrm{mmHg}$, and a pulmonary vascular resistance (PVR) $>3$ Wood units. ${ }^{1,11,12}$ The main symptom of PAH and CTEPH is dyspnea. ${ }^{1}$ Other symptoms of PAH and CTEPH include fatigue, weakness, and syncope. ${ }^{1,2,11}$ The vague symptomatology of PAH and CTEPH leads to diagnoses made most commonly at late stages of the diseases. ${ }^{7}$ Data from the REVEAL and French national registries indicate that $72 \%$ and $75 \%$ of patients with $\mathrm{PAH}$ when diagnosed are classified at World Health Organization functional class (WHO-FC) III and IV, respectively, indicating marked limitation of physical activity., ${ }^{4,13}$

\section{Treatment of Patients with PAH}

Until the 1990s, PAH was managed with support treatments directed against symptoms, which included anticoagulation therapy, diuretics, oxygen, and digoxin. ${ }^{14}$ Over the past 20 years, advances in our understanding of the pathogenesis of the disease have led to development of targeted therapeutics for PAH. Currently, there are 12 PAH pharmacotherapies approved by the U.S. Food and Drug Administration (FDA) in the United States. ${ }^{7}$ The therapies include a soluble guanylate cyclase stimulator (riociguat); endothelin receptor antagonists (e.g., ambrisentan, bosentan, and macitentan); phosphodiesterase-5 inhibitors (e.g., sildenafil and tadalafil); and prostacyclin analogs (e.g., epoprostenol, treprostinil, iloprost, and selexipag). ${ }^{1,7}$

Treatment goals for patients with PAH have recently been reported in a consensus statement from the Fifth World Symposium on Pulmonary Hypertension..$^{15}$ According to this statement, the goals of treatment are to improve functional class, improve 6-minute walk distance (6MWD) to >440 meters, achieve normalization of right ventricular size and function on an echocardiograph, achieve a decrease or normalization of B-type natriuretic peptide, and improve hemodynamics. ${ }^{15}$ Other treatment goals include to prevent disease progression, increase patient survival, and improve healthrelated quality of life., ${ }^{1,12,14}$ The statement suggests that specific PAH therapy should be augmented to achieve these goals. Similarly, the American College of Cardiology Foundation/ American Heart Association treatment guidelines and CHEST Guideline and Expert Panel Report support the use of combination therapy in patients with PAH who have an inadequate response to monotherapy. ${ }^{12,16}$ In clinical practice, many providers already adopt this practice of combination therapy. Based on the REVEAL Registry, 46\% of PAH patients were being treated with dual agents, and $9 \%$ were being treated with triple therapy. ${ }^{17}$ These data are similar to that reported in a study conducted in Germany, in which $43 \%$ of patients with PAH were reported as treated with a 2-drug regimen to achieve measurable stabilization of the disease..$^{18}$ Unfortunately, while achieving the goals outlined in the Fifth World Symposium statement are likely to be clinically relevant, no randomized clinical trials examining the superiority of such "goal-directed therapy" over conventional clinical management exist.

\section{Treatment of Patients with CTEPH}

Unlike PAH, CTEPH, in select cases, can be surgically treated and potentially cured via pulmonary endarterectomy (PEA), which is the preferred treatment in appropriate patients., ${ }^{1,2,19}$ PEA is used only when patients have surgically accessible disease and involves removing intraluminal scar tissue from the affected pulmonary arteries to reduce PVR and improve cardiac output. ${ }^{1}$ The procedure is highly successful and, for many patients, results in substantial improvement in 


\section{TABLE 1 Description and Interpretation of 6MWD, WHO-FC, and Clinical Worsening}

\section{Description}

Interpretation

6MWD: A measure of the distance an individual

is able to walk over a total of 6 minutes on a hard, flat surface

Change in 6MWD

- Assesses change in functional exercise capacity (i.e., indicator of ability to perform daily activities). ${ }^{34}$

- Most PAH medications have been FDA approved based on change in 6MWD as a primary endpoint of

clinical trials. 7

- Studies have reported a range (33-50 meters) of clinically meaningful changes in 6MWD

- Has modest validity as a surrogate endpoint for clinical outcomes. ${ }^{50}$

6MWD thresholds

- Absolute value of 6MWD.59

- There is no specific threshold value that is more clinically significant than any other. ${ }^{55}$

- The most widely used threshold as a treatment goal is $>440$ meters. ${ }^{15,59}$

- Certain thresholds may be appropriate for patients of different age groups, and comorbidities should be taken into consideration when determining the 6MWD threshold for the ideal treatment goal. ${ }^{59}$

Change in 6MWD as a component of a

composite endpoint

- A $15 \%$ reduction in the 6 MWD is clinically meaningful. ${ }^{55}$

- Useful as a component of clinical worsening. 55

WHO-FC: A means of classifying disease severity $\bullet$ Patients are placed into 1 of 4 WHO-FCs dependent on limits of physical activity. ${ }^{6}$

in PAH according to level of

with symptoms

- As WHO-FC increases from I to IV, limits of physical activity increase. ${ }^{61}$

- Systematic bias in clinician assignment of WHO-FC is common. ${ }^{67}$

Clinical worsening: Composite endpoint includ- • Clinical worsening can be predictive of proximate risk for subsequent major events (i.e., death,

ing all-cause mortality, hospitalization due to

transplantation, or atrial septostomy). 68

$\mathrm{PAH}$, and a component of disease progression

- The definition of clinical worsening has varied across studies and is not standardized. 68

$6 \mathrm{MWD}=6$-minute walking distance; FDA =U.S. Food and Drug Administration; PAH=pulmonary arterial hypertension; WHO-FC= World Health Organization

functional class.

symptoms, function, and quality of life. ${ }^{19}$ However, between $24 \%$ and $37 \%$ of patients with CTEPH have inoperable disease., ${ }^{90-22}$ Further, up to one third of CTEPH patients have persistent PH after PEA.9,22,23 Among these patients with either inoperable or residual CTEPH following PEA, the prescribing of PAH-specific medications (off-label) has increased, with results of a study using an international registry showing 54\% of patients with nonoperable CTEPH being treated with a PAHspecific medication. ${ }^{22}$ Currently, riociguat is the only FDAapproved medication (approved October 2013) for the indication of CTEPH. ${ }^{24}$

To guide management of patients with PAH and CTEPH it is necessary to have reliable prognostic markers of treatment responsiveness. Endpoints of randomized trials and patient registries are designed to be clinically meaningful; however, they may not directly be associated with healthcare-related economic outcomes of patients. ${ }^{25}$ In this review, we examined how endpoints from clinical trials and observational studies (i.e., patient registries) reflect patient outcomes for everyday clinical and formulary decision making.

A PubMed literature search was conducted to retrieve published studies, including randomized phase III clinical trials and observational studies, from years 2000 to May 2015 that evaluated the associations between change in 6MWD, 6MWD thresholds, change in WHO-FC, and clinical worsening with outcomes of patients with PAH and CTEPH. Descriptions and interpretation of these assessments are provided in Table 1.

\section{Assessments and Registries}

Assessments to evaluate treatment responsiveness among patients with PAH and CTEPH used in clinical trials have included assessment of functional capacity with the 6MWD test, Borg dyspnea score, WHO-FC, clinical worsening, survival, hemodynamics (e.g., lowering PAP, normalized cardiac output), and health-related quality of life measurements. ${ }^{1,5}$ Registries of patients with PAH and CTEPH have also provided substantial information on the characteristics and survival of patients with these diseases (Table 2)., ${ }^{40,26-33}$ Additionally, these registries have contributed meaningful information for identifying objective assessments that are associated with patient outcomes. ${ }^{27}$ The majority of the registries track endpoints similar to that of clinical trials and include changes in 6MWD, WHO/ New York Heart Association (NYHA)-FC, and survival., ${ }^{4,26-33}$

\section{Endpoints of Change}

For this review, we focused on the endpoints of change in 6MWD, 6MWD thresholds, change in 6MWD as a composite endpoint, change in WHO-FC, and time to clinical worsening, since clinical trial design task forces have recommended using endpoints that reflect disease progression. ${ }^{25}$

\section{6-Minute Walking Distance Test}

For PAH and CTEPH management, the 6MWD test is a commonly performed assessment. It is a measure of functional 


\section{TABLE 2 Registries Specific for Patients with PAH and CTEPH}

\begin{tabular}{|c|c|c|}
\hline Registry & Enrollment & Outcomes Measured \\
\hline $\begin{array}{l}\text { Registry to Evaluate Early and Long-term PAH Disease } \\
\text { Management (REVEAL) (U.S.)28 }\end{array}$ & 3,515 & $\begin{array}{l}\text { - WHO-FC } \\
\text { - } 6 \mathrm{MWD} \\
\text { - Cardiopulmonary exercise testing } \\
\text { - Pulmonary function testing } \\
\text { - Hemodynamic measurements } \\
\text { - Hospitalizations } \\
\text { - Deaths }\end{array}$ \\
\hline $\begin{array}{l}\text { Comparative, Prospective Registry of Newly Initiated Therapies } \\
\text { for Pulmonary Hypertension (COMPERA/COMPERA-KIDs) } \\
\text { (International) } 29\end{array}$ & $\sim 6,000$ & $\begin{array}{l}\text { - Survival by subgroup, by treatment strategy, and other factors } \\
\text { - Clinical predictors of short-term and long-term clinical outcomes } \\
\text { - Relationship between PAH medications and patient outcomes }\end{array}$ \\
\hline $\begin{array}{l}\text { EXPosure Registry RiociguaT in Patients with Pulmonary } \\
\text { Hypertension (EXPERT) (international) } 30\end{array}$ & $\sim 900$ & $\begin{array}{l}\text { - Number of adverse events/serious adverse events } \\
\text { - All-cause mortality }\end{array}$ \\
\hline $\begin{array}{l}\text { Assessing the Spectrum of Pulmonary Hypertension Identified at } \\
\text { a Referral Centre Registry (ASPIRE) (U.K.) }{ }^{20}\end{array}$ & 1,344 & $\begin{array}{l}\text { - Pulmonary function } \\
\text { - WHO-FC } \\
\text { - Shuttle walking test } \\
\text { - All-cause mortality }\end{array}$ \\
\hline National Audit of Pulmonary Hypertension (U.K.) ${ }^{26,31}$ & 482 & $\begin{array}{l}\text { - Pulmonary function tests } \\
\text { - } 6 \mathrm{MWD} \\
\text { - Echocardiography: reduction in peak pulmonary artery pressure } \\
\text { - Chest x-ray: reduction in cardiothoracic ratio } \\
\text { - Quality of life measures (Papworth protocol) } \\
\text { - Survival at } 6 \text { months and } 1 \text { year on prostaglandins and analogues }\end{array}$ \\
\hline 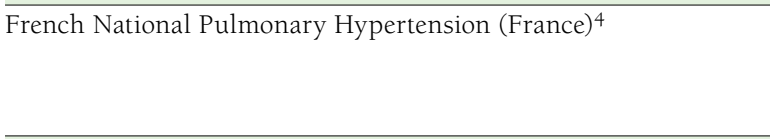 & 674 & $\begin{array}{l}\text { - } 6 \mathrm{MWD} \\
\text { - NYHA functional class } \\
\text { - Hemodynamics } \\
\text { - Survival }\end{array}$ \\
\hline Giessen Pulmonary Hypertension Registry (Germany) ${ }^{32}$ & 1,700 & $\begin{array}{l}\text { - Exercise capacity } \\
\text { - NYHA functional class } \\
\text { - Hemodynamics }\end{array}$ \\
\hline Swedish Pulmonary Hypertension Registry (SPAHR) (Sweden) ${ }^{33}$ & 252 & $\begin{array}{l}\text { - } 6 \mathrm{MWD} \\
\text { - NYHA functional class } \\
\text { - Hemodynamics } \\
\text { - Survival }\end{array}$ \\
\hline
\end{tabular}

6MWD =6-minute walking distance; CTEPH = thromboembolic pulmonary hypertension; NYHA = New York Heart Association; PAH = pulmonary arterial hypertension; WHO-FC = World Health Organization functional class.

limitation and correlates with peak aerobic capacity. ${ }^{34}$ The $6 \mathrm{MWD}$ test is convenient in that it is a simple, inexpensive, and reproducible test. ${ }^{34}$ During the 6MWD test, the degree of dyspnea (Borg scale) and oxygen saturation can also be evaluated..$^{35}$

Change in 6MWD. The change in 6MWD from baseline to trial endpoint has been used as the primary endpoint of several clinical trials involving patients with PAH and CTEPH and is widely accepted by regulatory agencies (Table 3). ${ }^{15,25,36-45}$ The use of the change in 6MWD as a primary endpoint in clinical trials is based on findings from studies which demonstrated that increases in 6MWD are associated with improved clinical outcomes among patients with PAH. ${ }^{46-48}$ Provencher et al. (2006) conducted a study of 103 patients with PAH and, using Cox regression analysis, found that each increase of 50 meters in 6MWD was associated with increased survival and event-free status. ${ }^{46}$ From a 12 -week sildenafil study, Gilbert et al. (2009) estimated a minimally clinically important dif- ference of 41 meters among patients with PAH that correlated with patient-reported improvement. ${ }^{48}$ Using a distributionaland anchor-based method, which relied on the relationship of change in 6MWD with patient-reported outcomes using the Physical Component Summary Score of the Medical Outcomes Study 36-item short form, Mathai et al. (2012) reported a minimal important difference (MID) of approximately 33 meters among 405 patients with $\mathrm{PAH}^{49}$ In this study, the anchor- and distributional-based estimates of the MID were similar and comparable to estimates of MID for other chronic lung diseases, including chronic obstructive pulmonary disease, emphysema, and idiopathic pulmonary fibrosis. ${ }^{49}$ Despite these studies reporting positive correlations between increased 6MWD and clinical outcome, the results of a pooled analysis of 10 randomized control trials concluded that change in 6MWD has only modest validity as a surrogate endpoint for clinical outcomes. $^{50}$ This pooled analysis revealed a threshold of 41.8 meters, meaning that if treatment with a medication improved 
TABLE 3 Summary of Endpoints of Randomized Phase III Clinical Trials of Patients with PAH and CTEPH, with Clinical Worsening Included as Primary or Secondary Endpoint

\begin{tabular}{|c|c|c|c|}
\hline Clinical Trial & Primary Endpoints & Secondary Endpoints & Definition of Clinical Worsening \\
\hline $\begin{array}{l}\text { Ambrisentan in Pulmonary Arterial } \\
\text { Hypertension, Randomized, } \\
\text { Double-Blind, Placebo-Controlled, } \\
\text { Multicenter, Efficacy (ARIES) } \\
\text { studies }^{36}\end{array}$ & $\begin{array}{l}\text { Change in 6MWD from } \\
\text { baseline to week } 12\end{array}$ & $\begin{array}{l}\text { - Time to clinical worsening } \\
\text { - Change in WHO-FC } \\
\text { - Change in quality of life } \\
\text { - Change in Borg dyspnea score } \\
\text { - Change in BNP concentration }\end{array}$ & $\begin{array}{l}\text { The time from randomization to the first } \\
\text { occurrence of death, lung transplantation, } \\
\text { hospitalization for PAH, atrial septostomy, } \\
\text { and study withdrawal because of addition } \\
\text { of other PAH medications or early escape } \\
\text { criteria }\end{array}$ \\
\hline $\begin{array}{l}\text { Bosentan: Randomized Trial of } \\
\text { Endothelin Receptor Antagonist } \\
\text { Therapy (BREATH-1) }\end{array}$ & $\begin{array}{l}\text { Change in 6MWD from } \\
\text { baseline to week } 16\end{array}$ & $\begin{array}{l}\text { - Time to clinical worsening } \\
\text { - Change in WHO-FC } \\
\text { - Change in Borg dyspnea score }\end{array}$ & $\begin{array}{l}\text { Time to death, lung transplantation, hospi- } \\
\text { talization for PH, lack of clinical improve- } \\
\text { ment or worsening leading to discontinua- } \\
\text { tion, need for epoprostenol therapy, or atrial } \\
\text { septostomy }\end{array}$ \\
\hline $\begin{array}{l}\text { Bosentan Effects in Inoperable } \\
\text { Forms of Chronic Thromboembolic } \\
\text { Pulmonary Hypertension study } \\
(\text { BENEFiT) })^{38}\end{array}$ & $\begin{array}{l}\text { - Change in PVR from base- } \\
\text { line to week } 16 \\
\text { - Change in 6MWD from } \\
\text { baseline to week } 16\end{array}$ & $\begin{array}{l}\text { - Change in WHO-FC } \\
\text { - Change in cardiac index } \\
\text { - Change in total pulmonary } \\
\text { resistance } \\
\text { - Change in mean right arterial } \\
\text { pressure } \\
\text { - Change in mPAP } \\
\text { - Change in mixed venous oxygen } \\
\text { saturation at rest } \\
\text { - Time to clinical worsening }\end{array}$ & $\begin{array}{l}\text { Time to death, lung transplantation, or } \\
\text { hospitalization due to worsening of } \mathrm{PH}\end{array}$ \\
\hline $\begin{array}{l}\text { Sitaxsentan To Relieve Impaired } \\
\text { Exercise (STRIDE-2) }\end{array}$ & $\begin{array}{l}\text { Change in 6MWD from } \\
\text { baseline to week } 18\end{array}$ & $\begin{array}{l}\text { - Change in WHO-FC } \\
\text { - Change in Borg dyspnea score } \\
\text { - Time to clinical worsening }\end{array}$ & $\begin{array}{l}\text { Time to death, lung transplantation, } \\
\text { hospitalization due to PAH, initiation of new } \\
\text { chronic PAH treatment, combined deterio- } \\
\text { ration in WHO-FC and } \geq 15 \% \text { decrease in } \\
6 \mathrm{MWD}\end{array}$ \\
\hline $\begin{array}{l}\text { Sitaxsentan To Relieve Impaired } \\
\text { Exercise-3 (STRIDE-4) } 40\end{array}$ & $\begin{array}{l}\text { Change in 6MWD from } \\
\text { baseline to week } 18\end{array}$ & $\begin{array}{l}\text { - Change in WHO-FC } \\
\text { - Time to clinical worsening }\end{array}$ & $\begin{array}{l}\text { Time to hospitalization for worsening PAH, } \\
\text { death, need for heart-lung or lung trans- } \\
\text { plant, atrial septostomy, or addition of any } \\
\text { new type of chronic treatment for PAH, or } \\
\text { a combination of deterioration in WHO-FC } \\
\text { and }>15 \% \text { decrease in 6MWD }\end{array}$ \\
\hline $\begin{array}{l}\text { Aerosolized Iloprost Randomized } \\
\text { study (AIR) } 41\end{array}$ & $\begin{array}{l}\text { - Increase of at least } 10 \% \text { in } \\
6 \mathrm{MWD} \\
\text { - Improvement in the } \\
\text { NYHA-FC in the absence } \\
\text { of a deterioration in the } \\
\text { clinical condition or death }\end{array}$ & $\begin{array}{l}\text { - Change in 6MWD } \\
\text { - Change in NYHA-FC } \\
\text { - Change in Mahler Dyspnea Index } \\
\text { score } \\
\text { - Change in hemodynamic variables } \\
\text { - Change in quality of life } \\
\text { - Clinical worsening }\end{array}$ & Death and need for transplantation \\
\hline $\begin{array}{l}\text { Sildenafil Use in Pulmonary } \\
\text { Hypertension study (SUPER) }{ }^{42}\end{array}$ & $\begin{array}{l}\text { Change in 6MWD from } \\
\text { baseline to week } 12\end{array}$ & $\begin{array}{l}\text { - Change in mPAP } \\
\text { - Change in Borg dyspnea score } \\
\text { - Change in WHO-FC } \\
\text { - Time to clinical worsening }\end{array}$ & $\begin{array}{l}\text { Time from randomization to death, } \\
\text { transplantation, hospitalization for PAH, or } \\
\text { initiation of additional therapies for PAH }\end{array}$ \\
\hline $\begin{array}{l}\text { Pulmonary Arterial Hypertension } \\
\text { and Response to Tadalafil study } \\
\text { (PHIRST) }{ }^{43}\end{array}$ & $\begin{array}{l}\text { Change in 6MWD from } \\
\text { baseline to week } 16\end{array}$ & $\begin{array}{l}\text { - Change in WHO-FC } \\
\text { - Time to clinical worsening } \\
\text { - Change in Borg dyspnea score } \\
\text { - Change in quality of life } \\
\text { - Change in hemodynamics } \\
\end{array}$ & $\begin{array}{l}\text { Time from randomization to death, lung or } \\
\text { heart-lung transplantation, atrial septostomy, } \\
\text { hospitalization due to worsening PAH, } \\
\text { initiation of new PAH-approved therapy, } \\
\text { worsening WHO-FC }\end{array}$ \\
\hline $\begin{array}{l}\text { Pulmonary Arterial Hypertension } \\
\text { Soluble Guanylate Cyclase-Stimulator } \\
\text { Trial (PATENT-1) }\end{array}$ & $\begin{array}{l}\text { Change in 6MWD from } \\
\text { baseline to week } 12\end{array}$ & $\begin{array}{l}\text { - Change in PVR } \\
\text { - Change in NT-proBNP } \\
\text { - Change in WHO-FC } \\
\text { - Time to clinical worsening } \\
\text { - Change in Borg dyspnea score } \\
\text { - Change in quality of life }\end{array}$ & $\begin{array}{l}\text { First occurrence of death, heart/lung trans- } \\
\text { plantation, atrial septosomy, hospitalization } \\
\text { due to worsening PAH, start of new specific } \\
\text { PAH treatment or modification of a pre- } \\
\text { existing prostanoid treatment due to worsen- } \\
\text { ing PAH, persistent decrease }>15 \% 6 \mathrm{MWD} \text {, } \\
\text { persistent worsening of WHO-FC }\end{array}$ \\
\hline $\begin{array}{l}\text { Chronic ThromboEmbolic Pulmonary } \\
\text { Hypertension sGC-Stimulator Trial } \\
(\text { CHEST-1) }\end{array}$ & $\begin{array}{l}\text { Change in 6MWD from } \\
\text { baseline to week } 16\end{array}$ & $\begin{array}{l}\text { - Change in PVR } \\
\text { - Change in NT-proBNP } \\
\text { - Change in WHO-FC } \\
\text { - Time to clinical worsening } \\
\text { - Change in Borg dyspnea score } \\
\text { - Change in quality of life }\end{array}$ & $\begin{array}{l}\text { First occurrence of death, heart/lung trans- } \\
\text { plantation, rescue PEA, hospitalization due } \\
\text { to worsening PH, start of new specific PH } \\
\text { treatment, persistent decrease }>15 \% 6 \mathrm{MWD} \text {, } \\
\text { persistent worsening of WHO-FC }\end{array}$ \\
\hline
\end{tabular}


TABLE 3 Summary of Endpoints of Randomized Phase III Clinical Trials of Patients with PAH and CTEPH, with Clinical Worsening Included as Primary or Secondary Endpoint (continued)

\begin{tabular}{|c|c|c|c|}
\hline Clinical Trial & Primary Endpoints & Secondary Endpoints & Definition of Clinical Worsening \\
\hline $\begin{array}{l}\text { Selexipag (ACT-293987) in } \\
\text { Pulmonary Arterial Hypertension, } \\
\text { GRIPHON Trial69 }\end{array}$ & $\begin{array}{l}\text { Time to first adjudicated } \\
\text { morbidity or mortality event }\end{array}$ & $\begin{array}{l}\text { - Change in 6MWD } \\
\text { - Change in Borg dyspnea score }\end{array}$ & $\begin{array}{l}\text { Time to death or hospitalization for worsen- } \\
\text { ing of PAH, worsening of PAH resulting in } \\
\text { need for lung transplantation, or atrial sep- } \\
\text { tostomy, initiation of parenteral prostanoid } \\
\text { therapy, chronic oxygen therapy, or disease } \\
\text { progression }\end{array}$ \\
\hline $\begin{array}{l}\text { Macitentan and Morbidity and } \\
\text { Mortality in Pulmonary Arterial } \\
\text { Hypertension (SERAPHIN) } 60\end{array}$ & $\begin{array}{l}\text { Time from initiation of } \\
\text { "treatment to first event } \\
\text { related to PAH }\end{array}$ & $\begin{array}{l}\text { - Change in 6MWD } \\
\text { - Change in WHO-FC } \\
\text { - Death due to PAH or } \\
\text { hospitalization for PAH } \\
\text { - Death from any cause }\end{array}$ & $\begin{array}{l}\text { Time to worsening of PAH, initiation of } \\
\text { treatment with intravenous or subcutaneous } \\
\text { prostanoids, lung transplantation, or atrial } \\
\text { septostomy, or death. Worsening of PAH } \\
\text { was defined by the occurrence of all } 3 \text { of the } \\
\text { following: a decrease in the } 6 \mathrm{MWD} \geq 15 \% \text {, } \\
\text { worsening of symptoms of PAH, and the } \\
\text { need for additional treatment for PAH }\end{array}$ \\
\hline $\begin{array}{l}\text { A Study of First-Line Ambrisentan } \\
\text { and Tadalafil Combination Therapy } \\
\text { in Subjects with Pulmonary Arterial } \\
\text { Hypertension (AMBITION) }\end{array}$ & $\begin{array}{l}\text { Number of patients and time } \\
\text { to first adjudicated clinical } \\
\text { failure event }\end{array}$ & $\begin{array}{l}\text { - Change in NT-proBNP } \\
\text { - Percentage of patients with a } \\
\text { satisfactory clinical response } \\
\text { - Change in 6MWD } \\
\text { - Change in WHO-FC } \\
\text { - Change in Borg dyspnea score }\end{array}$ & $\begin{array}{l}\text { Clinical failure defined as death, hospitaliza- } \\
\text { tion for worsening PAH, disease progression, } \\
\text { or unsatisfactory long-term clinical response }\end{array}$ \\
\hline $\begin{array}{l}\text { Beraprost-314d Added-on to } \\
\text { Treprostinil (BEAT) }{ }^{71}\end{array}$ & Time to clinical worsening & $\begin{array}{l}\text { - Change in 6MWD } \\
\text { - Change in Borg dyspnea score } \\
\text { - Change in WHO-FC } \\
\text { - Change in NT-proBNP }\end{array}$ & $\begin{array}{l}\text { Time from randomization to the first of any } \\
\text { of the following: death, hospitalization due } \\
\text { to worsening PAH, initiation of parenteral } \\
\text { prostacyclin, directly related to worsening } \\
\text { PAH, disease progression, and unsatisfactory } \\
\text { long-term clinical response }\end{array}$ \\
\hline
\end{tabular}

$6 \mathrm{MWD}$ over 12 weeks by $\geq 41.8$ meters versus treatment with placebo then the medication with $95 \%$ confidence is associated with a reduction in clinical event rate over 12 weeks.50 However, this change in $6 \mathrm{MWD}$ accounted for only $22 \%$ of the treatment effect. ${ }^{50}$

Recent evaluation of the relationship of a change in 6MWD and clinical worsening-free survival was conducted on the long-term results of the PATENT-2 and CHEST-2 trials. Twoyear results of the PATENT-2 trial showed a significant relationship between a 40-meter improvement from baseline in 6MWD and clinical worsening-free survival among patients with $\mathrm{PAH}$ (hazard ratio $[\mathrm{HR}]=0.80,95 \%$ confidence interval $[C I]=0.68-0.94, P=0.008){ }^{51,52}$ In the PATENT-2 trial, clinical worsening was defined as the first occurrence of any of the following events: death, heart/lung transplantation, atrial septostomy, hospitalization due to worsening of PAH, start of new PAH-specific treatment or modification of existing prostanoid treatment, persistent decrease of $>15 \%$ from baseline in 6MWD, and persistent worsening of WHO-FC. ${ }^{51,52}$ Also, 2-year results of the CHEST-2 trial showed a significant relationship between a 40-meter improvement from baseline in 6MWD and clinical worsening-free survival among patients with CTEPH $(\mathrm{HR}=0.77,95 \% \mathrm{CI}=0.61-0.97, \quad P=0.03) .{ }^{53,54}$ In the CHEST-2 trial, clinical worsening was defined similar to that in PATENT-2.53,54 These long-term results of the PATENT-2 and CHEST-2 trials provide supporting evidence that a 40-meter change from baseline in 6MWD is useful and clinically meaningful..$^{51-54}$

6MWD Thresholds. Farber et al. (2015) conducted an observational study using the REVEAL Registry, in which the prognostic value of the baseline 6MWD, absolute thresholds of the 6MWD, and change in the 6MWD were evaluated..$^{55}$ The findings of this study showed that regardless of the baseline threshold used ( $<165$ meters, 165-440 meters, $>440$ meters), 1-year survival estimates were lower for patients with a baseline 6MWD below the threshold than for patients with a baseline 6MWD above the threshold (Figure 1). ${ }^{55}$ These findings indicate that there is a survival advantage for patients with $\mathrm{PAH}$ associated with having a baseline 6MWD above predefined thresholds, but the study does not provide specific evidence supporting use of these certain thresholds as treatment goals. ${ }^{55}$ In fact, a recent study examining the utility of a goal-directed 6MWD strategy among patients with PAH in a PH Canadian registry failed to show a survival benefit at 1 and 2 years 


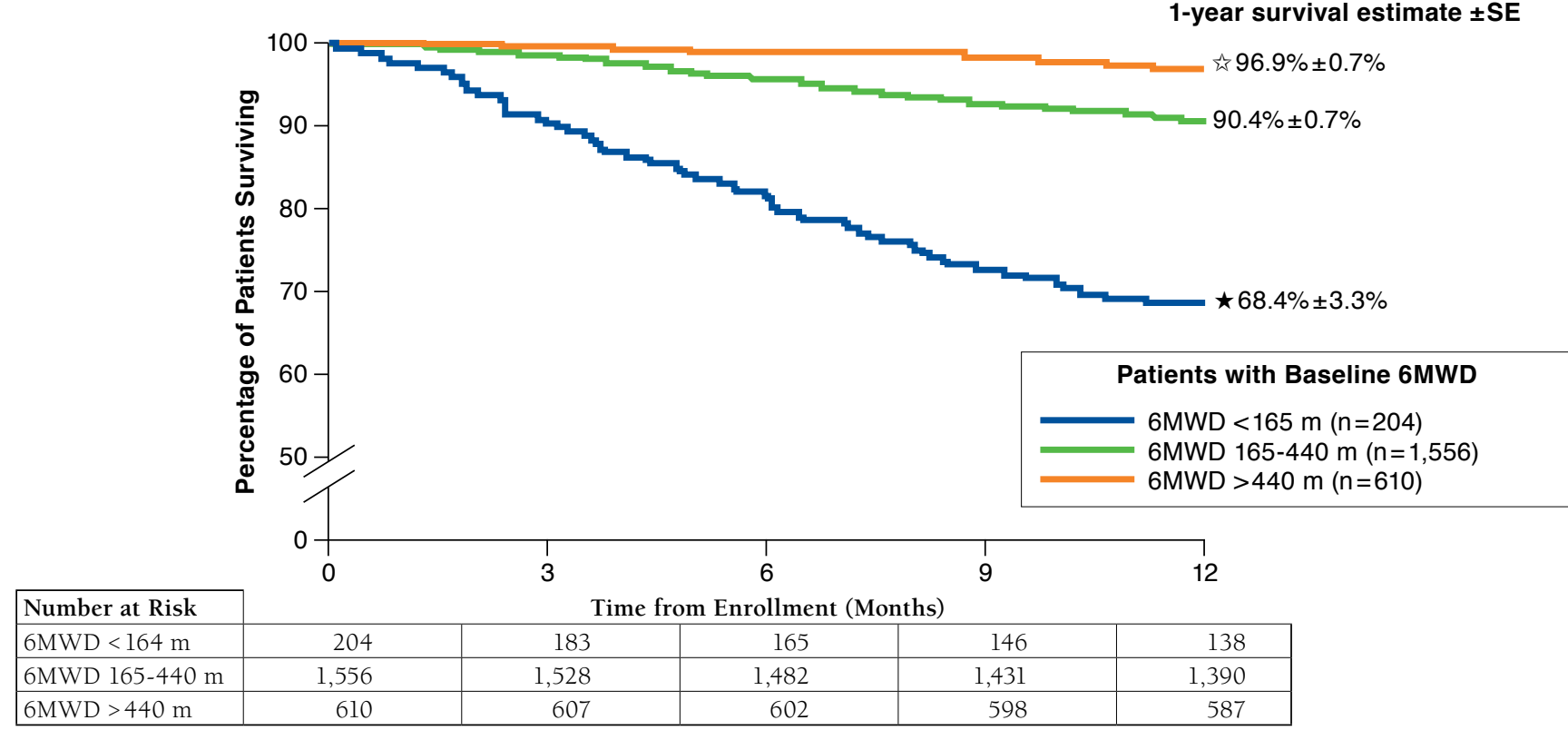

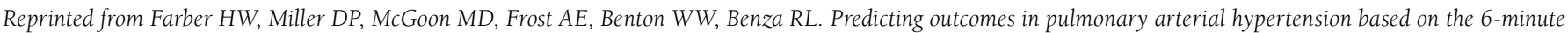
walk distance. J Heart Lung Transplant. 2015;34(3):362-68, Copyright (2015), Creative Commons Attribution from Elsevier.

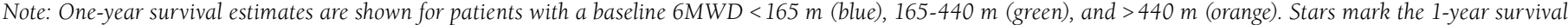
estimates for patients with a 6MWD of $>440-m$ threshold (white star) and patients with a 6MWD of $\leq 165-m$ threshold (black star).

$6 \mathrm{MWD}=6$-minute walking distance; $m=$ meter $; \mathrm{SE}=$ standard error.

when compared with conventional management. ${ }^{56}$ Given the previous failures of goal-directed therapies in other disease states (e.g., intensive glucose control to prevent cardiovascular complications in patients with type 2 diabetes, ${ }^{57}$ tight blood pressure control to prevent cardiovascular complications in hemodialysis patient ${ }^{58}$ ), further studies are needed to validate a goal-directed therapeutic strategy for patients with PAH. The recently published European Society of Cardiology (ESC) and the European Respiratory Society (ERS) guidelines have adopted the previous threshold of $>440$ meters as a treatment goal, although it is clarified in the guidelines that lower and higher thresholds may be appropriate for patients of different age groups and that comorbidities should also be taken into consideration when determining the 6MWD threshold for the ideal treatment goal. ${ }^{59}$

Change in 6MWD as a Component of a Composite Endpoint. Farber et al. reported that a $15 \%$ reduction in the 6MWD was associated with significantly lower survival at 1 year, but improvement in 6MWD was not associated with better survival. ${ }^{55}$ Thus, Farber et al. concluded that a $15 \%$ reduction in
6MWD may be clinically meaningful, and the use of a 15\% reduction in the 6MWD as a criterion for PAH worsening in clinical studies is supported. $.^{55} \mathrm{~A} \geq 15 \%$ decrease in 6MWD has been used as a component of the composite endpoint of time to clinical worsening in several clinical trials (Table 2). ${ }^{39,40,44,45,60}$

\section{World Health Organization Functional Class}

The functional classes (FCs) for categorizing patients with PAH were initially developed for patients with heart failure by the NYHA and then adapted to patients with PH by the WHO. ${ }^{61}$ $\mathrm{PH}$ patients are placed into 1 of 4 WHO-FCs dependent on limits of physical activity (e.g., WHO-FC III: Patients with pulmonary hypertension resulting in marked limitation of physical activity. They are comfortable at rest. Less than ordinary activity causes undue dyspnea or fatigue, chest pain, or near syncope). ${ }^{12,61}$ Several studies have demonstrated that FC is strongly predictive of survival/mortality among patients with PAH. ${ }^{1,12,62-64}$ An analysis of the REVEAL Registry demonstrated that patients with PAH who improved from FC III to FC I/II within 1 year had a significantly better 3-year survival than patients who remained in FC III or worsened to FC IV (84\% vs. 


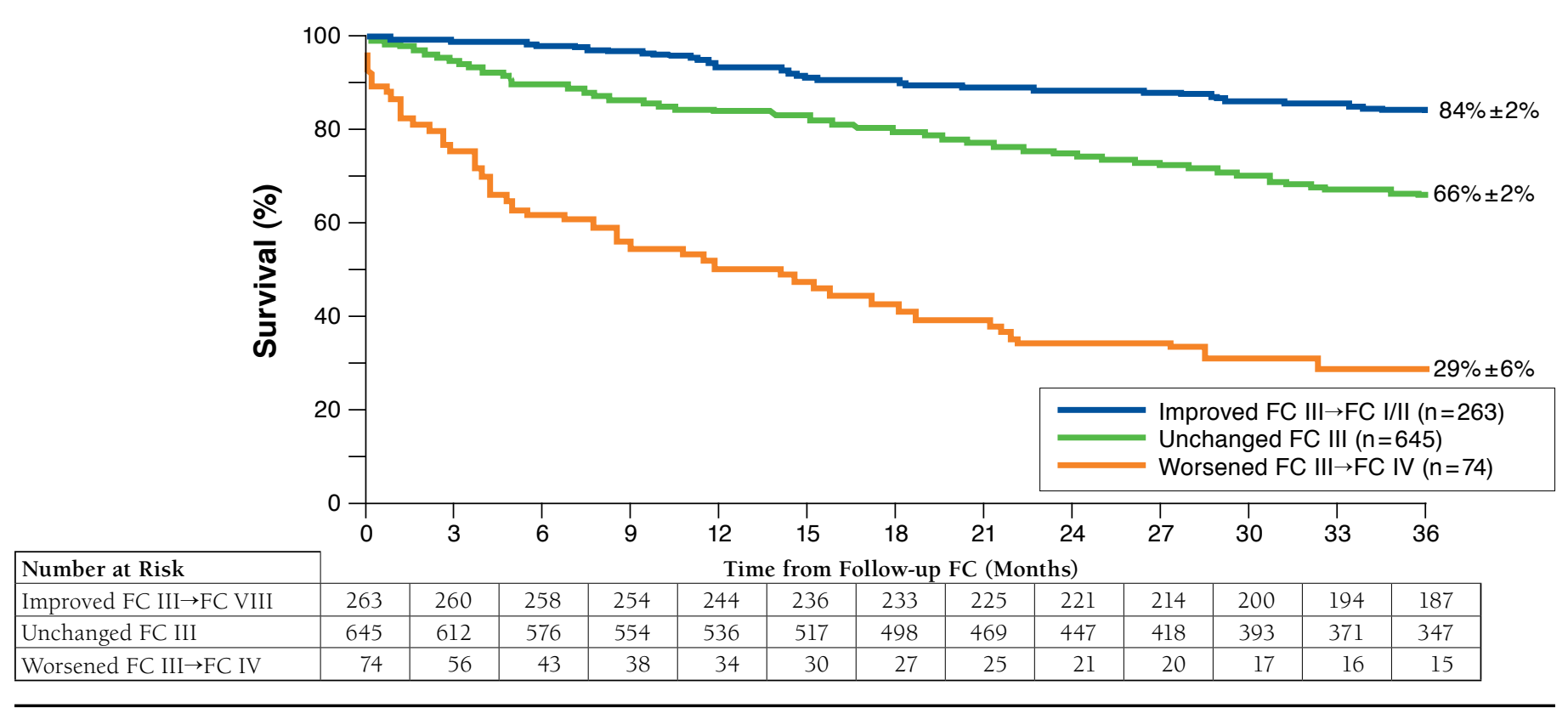

Reprinted from Barst RJ, Chung L, Zamanian RT, Turner M, McGoon MD. Functional class improvement and 3-year survival outcomes in patients with pulmonary arterial hypertension in the REVEAL Registry, Chest. 2013;144(1):160-68, Copyright (2013), with permission from Elsevier.

$F C=$ functional class; $P A H=$ pulmonary arterial hypertension.

66\%; Figure 2). ${ }^{64}$ The results of this REVEAL Registry analysis additionally showed that improvement in FC affects survival independently of PAH cause or time of diagnosis. ${ }^{64}$ Barst et al. (2013) concluded from this study that FC status is a meaningful clinical parameter. ${ }^{64}$ Furthermore, changes in 6MWD correlated with WHO-FC, such that 6MWD increased during the study period for those who improved in WHO-FC but decreased for those who worsened in WHO-FC. ${ }^{64}$ The results of Barst et al. were similar to that of Nickel et al. (2012), who conducted a prospective, single-center study of 109 patients with idiopathic PAH. ${ }^{64,65}$ In this study, a deterioration in WHO-FC between baseline and follow-up was associated with twice the risk of death $(\mathrm{HR}=2.0, P=0.02){ }^{65}$ Two-year results of the PATENT-2 and CHEST-2 trials did not show significant correlations between a deterioration in WHO-FC from baseline and survival among patients with PAH or CTEPH. ${ }^{52,54}$ However, they did show significant correlations between a deterioration in WHO-FC and clinical worsening-free survival (PATENT-2: $\mathrm{HR}=0.55,95 \% \mathrm{CI}=0.35-0.87, P=0.01$; $\mathrm{CHEST}-2$ : $\mathrm{HR}=0.47,95 \% \mathrm{CI}=0.27-0.84, P=0.01) .{ }^{52,54}$ The results of these studies provide strong evidence that WHO-FC is a prognostic indicator of survival/clinical worsening-free survival among patients with PAH or CTEPH..$^{52,54,62-65}$ The results of a German study conducted on patients with severe PH showed that exer- cise training plus medical therapy versus medical therapy alone reduces deterioration of WHO-FC, which is associated with less health care resource utilization. ${ }^{66}$

There are no other studies in the published literature showing any evidence supporting that changes in WHO-FC correspond with changes in health care resource utilization and costs. Limitations in the utility of WHO-FC as an outcome measurement for assessing response to therapy exist. For example, there is significant variability in the inter-rater reliability of assignment of FC as demonstrated by Taichman et al. (2009). ${ }^{67}$ In this study, clinicians highly familiar with PAH patients were asked to assign WHO-FC to several patient case scenarios. ${ }^{67}$ Responses varied widely; in fact, there was no agreement on WHO-FC for any of the case presentations, and systematic bias in assignment of WHO-FC between clinicians was found. ${ }^{67}$ These factors limit the utility of change in WHO-FC alone as a reliable tool in the assessment of response to therapy among patients with PAH or CTEPH.

\section{Clinical Worsening}

The Task Force on End Points and Clinical Trial Design at the Fourth World Symposium on Pulmonary Hypertension recommended that time to clinical worsening (TTCW), also referred to as clinical worsening and disease progression, 
be used as a primary endpoint in phase III trials.,13,25 This point was reiterated at the Fifth World Symposium in 2013 and also recommended by the 2008 Dana Point Task Force on End Points and Clinical Trial Design. ${ }^{67}$ The proposed definition of clinical worsening includes all-cause mortality, nonelective hospitalization for $\mathrm{PAH}$, and disease progression. ${ }^{1}$ The Fourth World Symposium task force recommended that disease progression be defined as "a reduction from baseline in the $6 \mathrm{MWD}$ by $15 \%$... plus worsening functional class (except for patients already in functional class IV)."1,68 Using the REVEAL Registry, Frost et al. (2013) validated clinical worsening as predictive of proximate (within 1 year) risk for subsequent major events (i.e., death, transplantation, or atrial septostomy). ${ }^{68}$ In this study of 3,001 patients with $\mathrm{PAH}$, freedom from clinical worsening was defined as freedom from (a) worsening FC, (b) a $\geq 15 \%$ reduction in $6 \mathrm{MWD}$, (c) all-cause hospitalization, or (d) the introduction of parenteral prostacyclin analog therapy. ${ }^{68}$ The study showed that among patients who survived without transplantation or septostomy $(77.7 \%$ vs. $94.1 \%, P<0.001)$, were newly diagnosed patients ( $74.6 \%$ vs. $90.3 \%, P<0.001)$, and previously diagnosed patients ( $77.6 \%$ vs. $95.1 \%, P<0.001$ ), those who clinically worsened in the first year had poorer survival in the subsequent year than those who did not. ${ }^{68}$ Among the overall study population, PAH patients with a clinical worsening event had a mean of 7.2 months until death. ${ }^{68}$ In this observational study, clinical worsening was highly predictive of subsequent proximate mortality, validating clinical worsening as a meaningful prognostic tool in clinical practice and as a primary endpoint in clinical trial design. ${ }^{68}$ The definition of clinical worsening used by Frost et al. was slightly different from that of the Fourth World Symposium task force in that all-cause hospitalization was used rather than nonelective hospitalization, and worsening FC and 6MWD were not required to be concurrent; thus, worsening FC or worsening 6MWD, rather than worsening FC and worsening 6MWD, was used in their definition. ${ }^{68}$

Clinical worsening has been included as a primary or secondary endpoint in several clinical trials (Table 2). ${ }^{36-45,60,69-71}$ However, the definition of clinical worsening varied across trials and was not standardized, so comparison of treatment efficacy using TTCW as the outcome measure is challenging. ${ }^{68}$ Significant differences in clinical worsening have not been observed in all trials with PAH-specific medications but have been in some, including ARIES-2 (ambrisentan vs. placebo), ${ }^{36}$ BREATH-1 (bosentan vs. placebo), ${ }^{37}$ and PATENT-1 (riociguat vs. placebo). ${ }^{44}$ The main drivers of significant differences in clinical worsening varied across trials but were most frequently a decrease in hospitalizations for $\mathrm{PH}$, deterioration in WHO-FC, a decrease in 6MWD, and initiation of a new PAH treatment. ${ }^{36,37,44}$ Significant differences in clinical worsening is an important attribute of a PAH-specific medication as it substantiates an indication for treatment of PAH to increase exercise ability and to decrease/delay clinical worsening. Having clinical worsening as a primary endpoint in clinical trials and using a universal definition will be useful for comparing treatments, especially among combination therapies, and also will assist in the identification of PAH and CTEPH patients who require therapy augmentation. ${ }^{17,68}$

\section{Discussion}

Management, including earlier diagnoses and advancement in pharmacologic treatments of patients with PAH and CTEPH, has improved in the recent past, and patients with these diseases are living longer. ${ }^{7}$ In view of the greater number of medications available to treat $\mathrm{PAH}$, the introduction of the first approved therapy to treat CTEPH, and the increasing use of combination pharmacotherapy, reliable prognostic markers of treatment responsiveness are important to help guide appropriate management. ${ }^{7,917}$ Based on this review of published literature, a reduction in 6MWD as a criterion for PAH worsening, a deterioration in WHO-FC, and delay in the time to clinical worsening are clinically meaningful trial endpoints and are associated with outcomes of patients with PAH and CTEPH. As previously mentioned, there are currently limitations for these endpoints, including that studies do not agree on the exact 6MWD change that correlates with patient outcomes; the definition of WHO-FCs varies among physicians and there is bias in assignment of WHO-FC; and that a universal definition of clinical worsening has not yet been used systematically in studies.

Utilization and standardization of these endpoints will be useful for comparing interventions of clinical trials and for goal-oriented therapy. Clinical trials involving patients with $\mathrm{PAH}$ and CTEPH are evolving to include a universal, composite endpoint of clinical worsening as a primary endpoint, which will help better define the effect of treatments on clinical outcomes that are notable for evaluating quality of care and costeffectiveness of treatments. ${ }^{14}$ This evolution is critical, since many studies have found that the health care and economic burdens of patients with PAH and CTEPH are substantial, ${ }^{72-81}$ although, because of the lack of specific coding for these rare diseases, there is a level of uncertainty regarding the true burden of PAH and CTEPH. Given the high health care costs of PAH and CTEPH patients, better management of both diseases with targeted pharmacotherapies may result in cost offsets 


\section{A Review of Clinical Trial Endpoints of Patients with Pulmonary Arterial Hypertension and Chronic Thromboembolic Pulmonary Hypertension and How They Relate to Patient Outcomes in the United States}

from reduced hospitalizations, lengthy hospital stays, and physician visits. From a U.S. payer perspective, clinical worsening is an important composite endpoint in that it includes hospitalization, which can be transformed into a preventative cost value associated with efficacious treatment of patients with PAH and CTEPH.

Except for the recently completed AMBITION trial, ${ }^{70}$ in which abrisentan monotherapy, tadalafil monotherapy, and abrisentan and tadalafil combination therapy were compared, there have been no published comparative studies across PAH-specific treatments; therefore, it is difficult to assess which treatments are "the most efficacious." The new ESC/ERS 2015 guidelines for diagnosis and treatment of $\mathrm{PH}$ give drug recommendations for monotherapy and combination therapy for the treatment of patients with PAH according to WHO-FC. ${ }^{59}$ However, because there are no head-to-head comparative studies of the different drugs, the guidelines do not propose a specific first-line therapy. ${ }^{59}$ The guidelines also do not specify if combination therapy should be used initially for patients with PAH WHO-FC II-III, but they do note that sequential combination therapy (i.e., first monotherapy then addition of a second and third drug in patients with inadequate clinical results) is the most widely used strategy in clinical trials and routine clinical practice. ${ }^{59}$ Thus, clinicians must use their best judgment to determine which patients may benefit from specific treatments. For patients with CTEPH, there is only 1 approved medication..$^{24}$

\section{Conclusions}

As new clinical trials and studies of patient registries are conducted, it will be important for them to maintain universal endpoints so that health care providers, decision makers, and payers can better understand the value of targeted pharmacotherapies and combination therapies for the treatment of patients with PAH and CTEPH.

\section{Authors}

CHRISTINE DIVERS, PhD; DAVID PLATT, MD; and EDWARD WANG, PharmD, MBA, Bayer HealthCare Pharmaceuticals, Whippany, New Jersey. JAY LIN, PhD, MBA, and MELISSA LINGOHR-SMITH, PhD, Novosys Health, Green Brook, New Jersey. STEPHEN C. MATHAI, MD, MHS, Johns Hopkins University School of Medicine, Baltimore, Maryland.

AUTHOR CORRESPONDENCE: Christine Divers, PhD, Director, HEOR Field Team, U.S. Health Economics and Outcomes Research, Bayer HealthCare Pharmaceuticals, 100 Bayer Blvd., Whippany, NJ 07981. Tel.: 919.924.8484; E-mail:christine.divers@bayer.com.

\section{DISCLOSURES}

Sponsorship for this review and article processing charges were funded by Bayer HealthCare Pharmaceuticals. Divers and Platt are employees of Bayer HealthCare Pharmaceuticals. Wang is an employee of Bayer HealthCare Pharmaceuticals and owns stock in the company. Lin and Lingohr-Smith are employees of Novosys Health, which received research funds from Bayer HealthCare Pharmaceuticals in connection with conducting this review and developing this manuscript. Mathai is a consultant to Bayer HealthCare Pharmaceuticals and also reports consulting fees from Actelion and Gilead.

Study concept and design were contributed by Divers, Platt, Lin, and Mathai. Lin and Lingohr-Smith collected the data, and data interpretation was performed by Divers, Platt, Wang, and Matthai. The manuscript was written primarily by Lingohr-Smith, with assistance from the other authors, and revised by Divers, Platt, Wang, and Mathai.

\section{REFERENCES}

1. McLaughlin VV, Archer SL, Badesch DB, et al.; American College of Cardiology Foundation Task Force on Expert Consensus Documents; the American Heart Association; the American College of Chest Physicians; the American Thoracic Society; the Pulmonary Hypertension Association. ACCF/AHA 2009 expert consensus document on pulmonary hypertension a report of the American College of Cardiology Foundation Task Force on Expert Consensus Documents and the American Heart Association. J Am Coll Cardiol. 2009;53(17):1573-619.

2. Hoeper MM, Eckhard M, Simonneau G, Rubin LJ. Chronic thromboembolis pulmonary hypertension. Circulation. 2006;113(16):2011-20.

3. Kirson NY, Birnbaum HG, Ivanova JI, Waldman T, Joish V, Williamson T. Prevalence of pulmonary arterial hypertension and chronic thromboembolic pulmonary hypertension in the United States. Curr Med Res Opin. 2011;27(9):1763-68

4. Humbert M, Sitbon O, Chaouat A, et al. Pulmonary arterial hypertension in France: results from a national registry. Am J Respir Crit Care Med. 2006;173(9):1023-30

5. Escribano-Subias P, Blanco I, Lopex-Meseguer M, et al.; REHAP Investigators. Survival in pulmonary hypertension in Spain: insights from the Spanish registry. Eur Resp J. 40(3):596-603

6. Bagalas V, Paspala A, Sourla E, et al. Chronic thromboembolic pulmonary hypertension: do not miss the chance for an early diagnosis. Am J Case Rep. 2014;15:378-81

7. Mandras SA, Gilkin RJ, Pruett JA, Raspa S. Pulmonary arterial hypertension: progress and challenges in the modern treatment era. Am J Manag Care. 2014;20(9 Suppl):S191-99.

8. Benza RL, Miller DP, Barst RJ, Badesch DB, Frost AE, McGoon MD. An evaluation of long-term survival from time of diagnosis in pulmonary arterial hypertension from the REVEAL Registry. Chest. 2012;142(2):448-56.

9. Condliffe R, Kiely DG, Gibbs SR, et al. Improved outcomes in medically and surgically treated chronic thromobembolic pulmonary hypertension. Am J Respir Crit Care Med. 2008;177(10):1122-27.

10. Pengo V, Lensing AW, Prins, et al.; Thromboembolic Pulmonary Hypertension Study Group. Incidence of chronic thromboembolic pulmonary hypertension after pulmonary embolism. N Engl J Med. 2004;350(22):2257-64.

11. Ozsu S, Cinarka J. Chronic thromboembolic pulmonary hypertension: medical treatment. Pulm Circ. 2013;3(2):341-44. 


\section{A Review of Clinical Trial Endpoints of Patients with Pulmonary Arterial Hypertension and Chronic Thromboembolic Pulmonary Hypertension and How They Relate to Patient Outcomes in the United States}

12. Galié N, Hoeper MM, Humbert M, et al.; ESC Committee for Practice Guidelines (CPG). Guidelines for the diagnosis and treatment of pulmonary hypertension: the Task Force for the Diagnosis and Treatment of Pulmonary Hypertension of the European Society of Cardiology (ESC) and the European Respiratory Society (ERS), endorsed by the International Society of Heart and Lung Transplantation (ISHLT). Eur Heart J. 2009;30(20):2493-537.

13. Frost AE, Badesch DB, Barst RJ, et al. The changing picture of patients with pulmonary arterial hypertension in the United States: how REVEAL differs from historic and non-U.S. contemporary registries. Chest. 2011;139(1):128-37.

14. Chen H, Taichman DB, Doyle RL. Health-related quality of life and patient reported outcomes in pulmonary arterial hypertension. Proc Am Thorac Soc. 2008;5(5):623-30.

15. McLauglin VV, Gaine SP, Howard LS, et al. Treatment goals of pulmonary hypertension. J Am Coll Cardiol. 2013;62(25 Suppl):D73-81.

16. Taichman DB, Ornelas J, Chung L, et al. Pharmacologic therapy for pulmonary arterial hypertension in adults: CHEST guideline and expert panel report. Chest. 2014;146(2):449-75.

17. McGoon MD, Miller DP. REVEAL: a contemporary U.S. pulmonary arterial hypertension registry. Eur Respir Rev. 2012;21(123):8-18.

18. Hoeper MM, Markevyvh I, Spiekerkoetter E, Welte T, Niedermeyer J. Goal-oriented treatment and combination therapy for pulmonary arterial hypertension. Eur Respir J. 2005;26(5)858-63.

19. Archibald CJ, Auger WR, Fedullo PF, et al. Long-term outcome after pulmonary thromboendarterectomy. Am J Respir Crit Care Med. 1999;160(2):523-28.

20. Hurdman J, Condliffe R, Elliot CA, et al. ASPIRE registry: assessing the Spectrum of Pulmonary hypertension Identifed at a REferral centre. Eur Respir J. 2012;39(4):945-55.

21. Bonderman D, Wilkens H, Wakounig S, et al. Risk factors for chronic thromboembolic pulmonary hypertension. Eur Respir J. 2009;33(2):325-31.

22. Pepke-Zaba J, Delcroix M, Lang I, et al. Chronic thromboembolic pulmonary hypertension: results from an international prospective registry. Circulation. 2011;124(18):1973-81.

23. Freed DH, Thomson BM, Berman M, et al. Survival after pulmonary thromboendarterectomy: effect of residual pulmonary hypertension. J Thorac Cardiovasc Surg. 2011;141(2):383-87

24. ADEMPAS (riociguat) tablets, for oral use. Bayer HealthCare

Pharmaceuticals. September 2014. Available at: http://www.accessdata.fda.gov/ drugsatfda_docs/label/2014/204819s002lbl.pdf. Accessed December 7, 2016.

25. Struder SM, Gilkin RJ. Clinical trial designs in PAH: shifting from functional measurements to long-term clinical outcomes. Am J Manag Care. 2014;20(6 Suppl):S115-22

26. Condliffe R, Kiely DG, Gibbs JS, et al. Prognostic and aetiological factors in chronic thromboembolic pulmonary hypertension. Eur Respir J. 2009;33(2):332-38

27. McGoon MD, Benza RL, Escribano-Subia P, et al. Pulmonary arterial hypertension: epidemiology and registries. J Am Coll Cardiol.

2013;62(25 Suppl):D51-59.

28. McGoon MD, Krichman A, Farber HW, et al. Design of the REVEAL registry for U.S. patients with pulmonary arterial hypertension. Mayo Clin Proc. 2008;83(8):923-31.
29. U.S. National Institutes of Health. COMPERA/COMPERA-KIDS. Available at: https://clinicaltrials.gov/ct2/show/NCT01347216. Accessed December 7, 2016.

30. U.S. National Institutes of Health. EXPERT, EXPosurE Registry RiociguaT in patients with pulmonary hypertension. Available at: https:// clinicaltrials.gov/ct2/show/NCT02092818. Accessed December 7, 2016.

31. Health \& Social Care Information Centre. National pulmonary hypertension audit. Leeds, West Yorkshire, U.K. Available at: http://www.hscic. gov.uk/ph. Accessed December 7, 2016

32. Voswinckel R, Gall H, Kierok S, et al. Registry of the University of Giessen Lung Center on new cases of pulmonary hypertension patients in years 1996-2005. Am J Respir Crit Care Med. 2009;179:A4905.

33. Fischler M, Speich R, Dorschner L, et al.; Swiss Society for Pulmonary Hypertension. Pulmonary hypertension in Switzerland: treatment and clinical course. Swiss Med Wkly. 2008;138(25-26):371-78.

34. Ross RM, Murthy JN, Wollak ID, Jackson AS. The six minute walk test accurately estimates mean peak oxygen uptake. BMC Pulm Med. 2010;10:31.

35. Farber HW. Validation of the 6-minute walk in patients with pulmonary arterial hypertension: trying to fit a square PEG into a round hole? Circulation. 2012;126(3):258-60.

36. Galié N, Olschewski H, Oudiz RJ, et al.; ARIES Group. Ambrisentan for the treatment of pulmonary arterial hypertension: results of the Ambrisentan in Pulmonary Arterial Hypertension, Randomized, DoubleBlind, Placebo-Controlled, Multicenter, Efficacy (ARIES) Study 1 and 2. Circulation. 2008;117(23):3010-19.

37. Rubin LJ, Badesch DB, Barst RJ, et al. Bosentan therapy for pulmonary arterial hypertension. N Engl J Med. 2002;346(12):896-903.

38. Jais X, D'Armini AM, Jansa P, et al. Bosentan for treatment of inoperable chronic thromboembolic pulmonary hypertension: BENEFiT (Bosentan Effects in iNopErable Forms of chronIc Thromboembolic pulmonary hypertension), a randomized, placebo-controlled trial. J Am Coll Cardiol. 2008;52(25):2127-34

39. Barst RJ, Langleben D, Badesch D, et al; STRIDE-2 Study Group. Treatment of pulmonary arterial hypertension with the selective endothelinA receptor antagonist sitaxsentan. J Am Coll Cardiol. 2006;47(10):2049-56.

40. Sandoval J, Torbicki A, Souza R, et al; STRIDE-4 Investigators. Safety and efficacy of sitaxsentan 50 and $100 \mathrm{mg}$ in patients with pulmonary arterial hypertension. Pulm Pharmacol Ther. 2012;25(1):33-39.

41. Olschewski H, Simonneau G, Galié N, et al; the Aerosolized Iloprost Randomized Study Group. Inhaled iloprost for severe pulmonary hypertension. N Engl J Med. 2002;347(5):322-29.

42. Galié N, Ghofrani HA, Torbicki A, et al; Sildenafil Use in Pulmonary Arterial Hypertension Study Group. Sildenafil citrate therapy for pulmonary arterial hypertension. N Engl J Med. 2005;353(20):2148-57.

43. Galié N, Brundage BH, Ghofrani HA, et al.; PHIRST Study Group. Tadalafil therapy for pulmonary arterial hypertension. Circulation. 2009;119(22):2894-903.

44. Ghofrani HA, Galié N, Grimminger F, et al; PATENT-1 Study Group. Riociguat for the treatment of pulmonary arterial hypertension. N Engl J Med. 2013;369(4):330-40.

45. Ghofrani HA, D'Armini AM, Grimminger F, et al; CHEST-1 Study Group. Riociguat for the treatment of chronic thromboembolic pulmonary hypertension. N Engl J Med. 2013;369(4):319-29. 


\section{A Review of Clinical Trial Endpoints of Patients with Pulmonary Arterial Hypertension and Chronic Thromboembolic Pulmonary Hypertension and How They Relate to Patient Outcomes in the United States}

46. Provencher S, Sitbon O, Humbert M, Cabrol S, Jais X, Simonneau G. Long-term outcome with first-line bosentan therapy in idiopathic pulmonary arterial hypertension. Eur Heart J. 2006;27(5):589-95.

47. Miyamoto S, Nagaya N, Satoh T, et al. Clinical correlates and prognostic significance of six-minute walk test in patients with primary pulmonary hypertension: comparison with cardiopulmonary exercise testing. Am J Respir Crit Care Med. 2000;161(2 Pt 1):487-92.

48. Gilbert C, Brown MC, Cappelleri JC, Carlsson M, McKenna SP. Estimating a minimally important difference in pulmonary arterial hypertension following treatment with sildenafil. Chest. 2009;135(1):137-42.

49. Mathai SC, Puhan MA, Lam D, Wise RA. The minimal important differences in the 6-minute walk test for patients with pulmonary arterial hypertension. Am J Respir Crit Care Med. 2012;186(5):428-33.

50. Gabler NB, French B, Strom BL, et al. Validation of 6-minute walk distance as a surrogate end point in pulmonary arterial hypertension trials. Circulation. 2012;126(3):349-56.

51. Rubin LJ, Galié N, Grimminger F, et al. Riociguat for the treatment of pulmonary arterial hypertension: a long-term extension study (PATENT-2). Eur Respir J. 2015;45(5):1303-13.

52. Rubin LJ, Galié N, Grimminger F, et al. Riociguat for the treatment of pulmonary arterial hypertension: 2-year results from the PATENT-2 long-term extension. Poster presented at: the European Respiratory Society Congress; September 6-10, 2014; Munich, Germany. Available at: http://erj.ersjournals.com/content/44/Suppl_58/P1803.short?relatedurls=yes\&legid=erj;44/Suppl_58/P1803. Accessed December 16, 2016.

53. Simonneau G, D'Armini AM, Ghofrani HA, et al. Riociguat for the treatment of chronic thromboembolic pulmonary hypertension: a long-term extension study (CHEST-2). Eur Respir J. 2015;45(5):1293-302.

54. Simmoneau G, D'Armini AM,Ghofrani $\mathrm{H}$, et al. Riociguat for the treatment of chronic thrombembolic pulmonary hypertension: 2-year results from the CHEST-2 long-term extension. Poster presented at: the European Respiratory Society Congress; September 6-10, 2014; Munich, Germany. Available at: http://erj.ersjournals.com/content/44/Suppl_58/P1802. Accessed December 16, 2016.

55. Farber HW, Miller DP, McGoon MD, Frost AE, Benton WW, Benza RL Predicting outcomes in pulmonary arterial hypertension based on the 6-minute walk distance. J Heart Lung Transplant. 2015;34(3):362-68.

56. Porhownik NR, Myers R, Bshouty Z. Directing therapy in pulmonary arterial hypertension using a target 6 min walk distance. Can Resp J. 2013:20(2):111-15

57. ADVANCE Collaborative Group, Patel A, MacMahon S, et al. Intensive blood glucose control and vascular outcomes in patients with type 2 diabetes. N Engl J Med. 2008;358(24):2560-72.

58. Chang TI. Systolic blood pressure and mortality in patients on hemodialysis. Curr Hypertens Res. 2011;13(5):362-69.

59. Galié N, Humbert M, Vachiery JL, et al. 2015 ESC/ERS Guidelines for the diagnosis and treatment of pulmonary hypertension: the Joint Task Force for the Diagnosis and Treatment of Pulmonary Hypertension of the European Society of Cardiology (ESC) and the European Respiratory Society (ERS). Endorsed by: Association for European Paediatric and Congenital Cardiology (AEPC), International Society for Heart and Lung Transplantation (ISHLT). Eur Heart J. 2016;37(1):67-119.

60. Pullido T, Adzerikho I, Channick RN, et al; SERAPHIN Investigators. Macitentan and morbidity and mortality in pulmonary arterial hypertension. N Engl J Med. 2013;369(9):809-18.
61. Barst RJ, Gibbs JS, Ghofrani HA, et al. Updated evidence-based treatment algorithm in pulmonary arterial hypertension. J Am Coll Cardiol. 2009;54(1 Suppl):S78-84.

62. McLaughlin VV, Shillington A, Rich S. Survival in primary pulmonary hypertension: the impact of epoprostenol therapy. Circulation. 2002;106(12):1477-82.

63. Benza RL, Miller DP, Gomberg-Maitland M, et al. Predicting survival in pulmonary arterial hypertension: insights from the Registry to Evaluate Early and Long-Term Pulmonary Arterial Hypertension Disease Management (REVEAL). Circulation. 2010;122(2):164-72.

64. Barst RJ, Chung L, Zamanian RT, Turner M, McGoon MD. Functional class improvement and 3-year survival outcomes in patients with pulmonary hypertension in the REVEAL Registry. Chest. 2013;144(1):160-68.

65. Nickel N, Golpon H, Greer M, et al. The prognostic impact of follow-up assessments in patients with idiopathic pulmonary arterial hypertension. Eur Respir J. 2012;39(3):589-96.

66. Ehlken N, Verduyn C, Tiede H, et al. Economic evaluation of exercise training in patients with pulmonary hypertension. Lung. 2014;192(3):359-66.

67. Taichman DB, McGoon MD, Harhay MO, et al. Wide variation in clinicians' assessment of New York Heart Association/World Health Organization functional class in patients with pulmonary arterial hypertension. Mayo Clin Proc. 2009;84(7):586-92.

68. Frost AE, Badesch DB, Miller DP, Benza RL, Meltzer LA, McGoon MD. Evaluation of the predictive value of a clinical worsening definition using 2-year outcomes in patients with pulmonary arterial hypertension: a REVEAL Registry analysis. Chest. 2013;144(5):1521-29.

69. Skoro-Sajer N, Lang IM. Selexipag for the treatment of pulmonary arterial hypertension. Expert Opin Pharmacother. 2014;15(3):429-36.

70. Galié N, Barbera JA, Frost AE, et al.; AMBITION Investigators. Initial use of ambrisentan plus tadalfil in pulmonary arterial hypertension. N Engl J Med. 2015;373(9):834-44.

71. Beraprost-314d Added-on to Treprostinil (BEAT). Clinicaltrials.gov (Identifier NCT01908699). Available at: https://clinicaltrials.gov/ct2/show/NCT 01908699?term=beraprost+treprostinil\&rank=1. Accessed December 7, 2016.

72. Burke JP, Hunsche E, Requlier E, Nagao M, Buzinec P, Drake W III. Characterizing pulmonary hypertension-related hospitalization costs among Medicare Advantage or commercially insured patients with pulmonary arterial hypertension: a retrospective database study. Am J Manag Care. 2015;21(3 Suppl):S47-58

73. Sikirica M, Iorga SR, Bancroft T, Potash J. The economic burden of pulmonary arterial hypertension (PAH) in the U.S. on payers and patients. BMC Health Serv Res. 2014;14(1):1.

74. Said Q, Martin BC, Joish VN, Kreilick C, Mathai SC. The cost to managed care of managing pulmonary hypertension. J Med Econ. 2012;15(3):500-08

75. Kirson NY, Birnbaum HG, Ivanova JI, et al. Excess costs associated with patients with pulmonary arterial hypertension in a U.S. privately insured population. Appl Health Econ Health Policy. 2011;9(5):293-303.

76. Kirson NY, Birnbaum HG, Ivanova JI, Waldman T, Joish V, Williamson T. Excess costs associated with patients with chronic thromboembolic pulmonary hypertension in a U.S. privately insured population. Appl Health Econ Health Policy. 2011;9(6):377-87.

77. Burger CD, Long PK, Shah MR, et al. Characterization of first-time hospitalizations in patients with newly diagnosed pulmonary arterial hypertension in the REVEAL registry. Chest. 2014;146(5):1263-73. 
A Review of Clinical Trial Endpoints of Patients with Pulmonary Arterial Hypertension and Chronic Thromboembolic Pulmonary Hypertension and How They Relate to Patient Outcomes in the United States

78. Johnson, S, Delate T, Boka A, Shaw P, Zager C. Characterizing the financial burden of pulmonary arterial hypertension within an integrated healthcare delivery system. J Med Econ. 2013;16(12):1414-22.

79. Copher R, Cerulli A, Watkins A, Monsalvo M. Treatment patterns and healthcare system burden of managed care patients with suspected pulmonary arterial hypertension in the U.S. J Med Econ. 2012;15(5):947-55.
80. Berger A, Edelsberg J, Teal S, Mychaskiw MA, Oster G. Changes in healthcare utilization and costs associated with sildenafil therapy for pulmonary arterial hypertension: a retrospective cohort study. BMC Pulm Med. $2012 ; 12: 75$

81. Angalakuditi M, Edgell E, Beardsworth A, Buysman E, Bancroft T. Treatment patterns and resource utilization and costs among patients with pulmonary arterial hypertension. J Med Econ. 2010;13(3):393-402. 